Revista de Economia Política, vol. 31, $n^{\circ} 2$ (122), pp. 315-335 abril-junho/2011

\title{
Desdobramentos da crise financeira internacional
}

O Dossiê da Crise II foi publicado em agosto de 2010 pela Associação Keynesiana Brasileira (AKB). Neste Dossiê procura-se avaliar os desdobramentos da crise financeira internacional, no mundo em geral e no Brasil. Publicamos abaixo alguns dos artigos do referido Dossiê (a relação completa dos artigos pode ser encontrada no sítio da Associação: http://www.ppge.ufrgs.br/akb).

\section{Tempos Keynesianos}

\author{
LUIZ FERNANDO DE PAULA ${ }^{1}$ \\ E FERNANDO FERRARI FILHO ${ }^{2}$
}

O processo de globalização financeira, em que os mercados financeiros são integrados de tal forma a criar um "único" mercado mundial de dinheiro e crédito, diante de um quadro em que inexistem regras monetário-financeiras e cambiais estabilizantes e os instrumentos tradicionais de política macroeconômica tornam-se crescentemente insuficientes para conter os colapsos financeiros (e cambiais) em nível mundial, tem resultado em frequentes crises de demanda efetiva, determinado fundamentalmente por "forças financeiras".

De fato, a crise financeira que emergiu em 2007-2008, cujos desdobramentos ainda se fazem sentir nos dias de hoje, é, sobretudo, a crise da globalização financeira, entendida como uma tendência à criação de um mercado financeiro global e de intensificação no fluxo de capitais entre países. Esse processo remonta a crise do sistema de Bretton Woods e a formação do mercado de eurodólares, que, diga-se de passagem, acabou contribuindo para a desregulamentação doméstica dos sistemas financeiros - com o fim da segmentação entre mercados - e a liberalização dos fluxos de capitais.

Como resultado do processo de desregulamentação financeira, observou-se um acirramento na concorrência entre instituições bancárias e, por conseguinte, queda nas margens de intermediação financeira, tendo como resposta uma tendência à conglomeração financeira e um aumento na escala de operação, via fusões e aquisições. Assim, instituições financeiras passaram a explorar diferentes mercados, inclusive de mais baixa renda. No mercado de títulos, desenvolveram-se mecanismos de securitização, estimulados pelo crescimento de investidores institucionais, em que firmas e bancos se financiam

\footnotetext{
${ }^{1}$ Professor adjunto da Universidade do Estado do Rio de Janeiro (UERJ) e presidente da Associação Keynesiana Brasileira (AKB). E-mail: luizfpaula@terra.com.br.

${ }^{2}$ Professor titular da Universidade Federal do Rio Grande do Sul (UFRGS) e vice-presidente da AKB. E-mail: ferrari@ufrgs.br.
} 
“empacotando" rendas a receber. Em suma, uma vez que a securitização permitia a diluição de riscos no mercado, as instituições financeiras passaram a aumentar sua alavancagem, supondo que os mecanismos de autorregulação do mercado seriam capazes de continuar avaliando corretamente os riscos inerentes às atividades financeiras.

A crise do subprime - mercado de financiamento imobiliário de maior risco - acabou por expressar todas as contradições deste processo. A necessidade de ampliação de escala levou as instituições financeiras a incorporarem segmentos de baixa renda em condições de "exploração financeira" - no caso do subprime, com taxas de juros variáveis (baixas no início e se elevando ao longo do tempo) que acabou resultando em um processo de estrangulamento financeiro do tomador de crédito. A securitização, que serviria para diluir riscos, na prática serviu para esconder riscos — títulos lastreados em hipotecas eram emitidos por instituições financeiras de grande porte, sendo tais ativos classificados como grau de investimento por uma agência de rating. Tais ativos, como resultado da globalização financeira, passaram, por sua vez, a ser comprados por investidores de diferentes nacionalidades. Criaram-se, assim, novos instrumentos financeiros que não foram devidamente regulamentados pelas autoridades. Mecanismos de auto-regulação mostraram-se falhos devido ao caráter pró-cíclico da tomada de risco: projetos que eram considerados ruins na desaceleração passaram a ser visto como bons no boom cíclico.

John Maynard Keynes, em sua Teoria Geral do Emprego, do Juros e da Moeda (TG) de 1936, chamava a atenção para o fato de que, em economias monetárias da produção, a organização dos mercados financeiros enfrenta um trade-off entre liquidez e investimento: por um lado, eles estimulam o desenvolvimento da atividade produtiva ao tornar os ativos mais líquidos, liberando, portanto, o investidor da irreversibilidade do investimento; por outro, aumenta as possibilidades de ganhos especulativos. Assim, ao estabelecer uma conexão entre os mercados financeiro e real da economia, Keynes na TG (1964, p. 159) escreve que "a posição é séria quando o empreendimento torna-se uma bolha sobre o redemoinho da especulação. Quando o desenvolvimento das atividades de um país torna-se o subproduto das atividades de um cassino, o trabalho provavelmente será malfeito”.

Indo ao encontro de Keynes, nos dias de hoje, a ação dos global players, em um mercado mais liberalizado e integrado, faz com que os mercados financeiros convertam-se em uma espécie de grande cassino global. Especulação, em uma economia global, tem caráter disruptivo não somente em mercados domésticos, mas sobre países como um todo, criando uma espécie de cassino financeiro ampliado. $\mathrm{Na}$ perspectiva keynesiana, instabilidade financeira não é vista como "anomalia”, mas como resultante da própria forma de operação dos mercados financeiros em um sistema no qual não existe uma estrutura de salvaguarda que exerça o papel de um market marker global. Assim, o formato institucional específico dos mercados financeiros determina as possibilidades de se ter um ambiente em que a especulação possa florescer. Crises financeiras não são apenas resultados de comportamentos "irracionais" dos agentes, mas resultam da própria forma de operação dos mercados financeiros globais liberalizados sem um sistema de regulação adequado.

A crise financeira internacional, cuja origem está nas perdas causadas pelo crescente default dos empréstimos das hipotecas de alto risco do mercado subprime norte-americano e que, devido ao fato de que grande parte dessas hipotecas foram securitizadas e distribuídas a investidores do mercado global, acabou tornando-se global, nos induz a duas reflexões. Em primeiro lugar, ela põe em xeque os benefícios concretos da globalização financeira, com mercados financeiros desregulados, inclusive nos países desenvolvidos. Em segundo lugar, ela nos remete, a partir das medidas de natureza fiscal e monetária implementadas pelos países desenvolvidos e, em menor grau, por países em desenvolvimento — tais como injeção de liquidez e de capital nos sistemas financeiros por parte das autoridades econômicas destes países e redução sincronizada da taxa básica de juros dos principais bancos centrais mundiais - para se evitar a repetição de uma grande depressão, tanto a repensar o próprio papel do Estado na economia, quanto à necessidade de re-regulamentar os sistemas financeiros domésticos e reestruturar o sistema monetário internacional.

Recentemente, um artigo escrito por economistas do Fundo Monetário Internacional (Blanchard, O. et al., "Rethinking macroeconomic policy", fevereiro de 2010) defende, em tempos pós-crise, uma nova agenda de política econômica alternativa ao "consenso macroeconômico" prevalecente até a 
crise econômica de $2008^{3}$. Segundo este trabalho, os fundamentos desse consenso foram seriamente abalados com a crise econômica. Em primeiro lugar, a crise mostrou aos formuladores de política econômica que a manutenção de uma taxa estável de inflação não é condição suficiente para a estabilidade macroeconômica. Isso porque o comportamento dos preços dos ativos, dos agregados de crédito e, até mesmo, a composição da produção podem criar forças desestabilizadoras dentro do sistema econômico que levam, a médio e longo prazo, à ocorrência de uma crise financeira de grandes proporções. Em segundo lugar, a fixação de uma meta de inflação muito baixa reduz consideravelmente o espaço para a redução da taxa nominal de juros quando a mesma for necessária para se lidar com os efeitos de uma crise financeira. Assim, os custos da perda de flexibilidade de uma meta de inflação muito baixa superam, em muito, os possíveis ganhos de credibilidade que possam gerar. Em terceiro lugar, a manutenção de um "espaço fiscal" - entendido como uma relação dívida bruta/PIB entre baixa e moderada - se mostrou de importância fundamental para uma pronta e decisiva resposta da política fiscal à crise financeira. Por fim, o escopo limitado da regulação financeira forneceu os incentivos necessários para os bancos criarem operações "exóticas" fora do seu balanço, de forma a contornar os limites de alavancagem estabelecidos pelo Acordo da Basileia, o que acabou por aumentar a fragilidade financeira do sistema como um todo ${ }^{4}$.

Enfim, o próprio mainstream, ou parte dele, questiona os fundamentos da política econômica convencional e mesmo os próprios fundamentos da teoria econômica ortodoxa, como a fé cega no funcionamento do mercado, em que a ação de agentes racionais conduziria a resultados "ótimos" (ou próximos a esses) do ponto de vista econômico-social. De fato, há muito economistas keynesianos vêm questionando tais preceitos, chamando a atenção que o modelo "neoliberal" não garante um crescimento econômico robusto e financeiramente estável, além de gerar um crescimento incompatível com a melhoria na distribuição de renda. Para esses economistas, não só Keynes e seus seguidores têm muito a dizer sobre a "economia da depressão", como também sobre caminhos possíveis para se alcançar uma "economia da prosperidade". Enfim, está claro que vivemos "tempos keynesianos", embora os contornos da política econômica que assegure a saída definitiva da crise e, sobretudo, para um mundo pós-crise não estejam muito claros no debate econômico atual. Afinal, os sinais de recuperação econômica mundial têm sido contrastados com sinais preocupantes, tais como o dólar e a economia norte-americana continuam fragilizados e o sistema financeiro dos países da zona do euro apresenta sérias instabilidades, principalmente devido à crise fiscal dos chamados PIIGS (Portugal, Itália, Irlanda, Grécia e Espanha), e o fato de que a moderada recuperação econômica no mundo tem sido acompanhada de hesitante diminuição no desemprego.

Diante desse contexto, a AKB elaborou o Dossiê da Crise II, cujo objetivo consiste em avaliar os desdobramentos da crise financeira internacional, no mundo em geral e no Brasil, assim como apresentar algumas alternativas de políticas. Nele, algumas questões centrais são analisadas, tais como: a crise financeira internacional resulta de uma crise de um paradigma econômico liberal? Quais os motivos da hesitante recuperação econômica mundial? O que está por detrás da crise na Europa? No caso do Brasil, quais foram os fatores determinantes na superação da crise? Passado o susto, quais problemas econômicos devem ser enfrentados e quais devem ser as soluções para os mesmos?

\footnotetext{
${ }^{3}$ Para o referido consenso a política macroeconômica deveria ser conduzida com base nos seguintes princípios: 1) fixação de um único objetivo para a política monetária: obtenção de uma taxa de inflação baixa e estável; 2) a política monetária, conduzida sob um regime de metas de inflação, deve ter como único instrumento a taxa de juros de curto prazo; 3 ) o único objetivo da política fiscal deve ser a estabilização da dívida bruta do setor público como proporção do PIB; e 4) a regulação financeira deve ser pensada de forma independente dos impactos macroeconômicos da mesma.
}

${ }^{4}$ Veja, por exemplo, Oreiro, J.L. e Paula, L.F. “Um novo arcabouço de política econômica”, Valor $30 / 03 / 2010$. 


\section{A exaustão do paradigma de crescimento da economia americana ${ }^{5}$}

THOMAS I. PALLEY ${ }^{6}$

A economia americana está em recessão e os problemas relacionados ao elevado endividamento das famílias criam temores de que essa recessão pode ser mais prolongada e severa do que as recessões de 1991 e 2000. O Federal Reserve e o Tesouro tomaram medidas sem precedentes na história para estimular a economia por intermédio de reduções da taxa de juros, injeções de liquidez e cortes de impostos, todas as quais são inteiramente justificadas, mas são apenas um paliativo de curto prazo.

Certamente que os Estados Unidos devem se preocupar com a recuperação cíclica de sua economia, mas também é necessário que nós, americanos, nos preocupemos com o fato de que o paradigma de crescimento que impulsionou a nossa economia ao longo das últimas décadas está esgotado. Isso também tem implicações para a economia mundial, dado que essa tem se apoiado nos Estados Unidos como "comprador de última instância". Se a economia americana crescer mais devagar, não está claro como os outros países terão a capacidade ou a vontade de desenvolver motores alternativos de crescimento.

A expansão econômica recente começou em novembro de 2001, tendo se caracterizado por um longo período de "crescimento sem emprego" do nível de atividade econômica, sendo que, ao longo da maior parte do período de expansão, o crescimento do emprego permaneceu próximo de zero. Isso levou o Federal Reserve a reduzir as taxas de juros apesar da recuperação da atividade econômica, a mantê-las baixas por um longo período de tempo e a aumentá-las de forma lenta e gradual a partir de então. As ações do Federal Reserve impediram uma recaída na recessão, mas também levaram ao surgimento de uma bolha no mercado imobiliário. Essas ações também desencadearam uma busca por rendimentos mais altos por parte dos investidores, levando-os a desconsiderar o risco, o qual acabou de manifestando na forma de deflação dos preços das casas e perdas maciças nos mercados de crédito.

Por que a expansão foi tão fraca apesar das reduções de impostos ocorridas em 2001 e os grandes aumentos com gastos militares e com a segurança nacional? A resposta para essa pergunta encontra-se no dólar sobrevalorizado e no déficit comercial que drenou os gastos, empregos e investimento para fora da economia. De fato, a indústria perdeu 1,8 milhão de empregos entre o final de 2001 e o final de 2007. Esse é um fato sem precedentes na história americana, pois nunca a indústria havia perdido empregos durante uma expansão.

A política americana de dólar forte tem uma responsabilidade razoável pelo déficit comercial. Essa política foi iniciada pela administração Bill Clinton, sob o conselho do Secretário do Tesouro Robert E. Rubin, sendo continuada na administração George Bush. O efeito foi tornar as importações mais baratas e as exportações mais caras, induzindo, portanto, a um aumento das importações, uma redução das exportações e o encorajamento da transferência de produção para o exterior. Isso, por seu turno, gerou cortes de emprego na indústria, reduções na capacidade de produção e no investimento doméstico na produção manufatureira.

A política comercial também desempenhou um papel significativo nesse processo ao encorajar as empresas americanas a moverem suas plantas para o exterior. Em conjunto com essas tendências devemos destacar as políticas de crescimento puxado pelas exportações adotadas pela China e outros países do leste asiático. Essas políticas promoveram as exportações asiáticas e o investimento externo direto nessas econômicas, prejudicando, assim, as exportações americanas.

O déficit comercial e o desprezo pela indústria são parte de um paradigma de política econômica mais amplo adotado desde 1980, o qual criou um novo tipo de ciclo de negócios. As flutuações cíclicas durante as administrações de Ronald Reagan, George H.W. Bush, Bill Clinton e George W. Bush possuem grandes similaridades entre si e são bastante diferentes dos ciclos observados antes de 1980. As similaridades referem-se ao descompasso entre o crescimento dos salários com respeito ao crescimento

\footnotetext{
${ }^{5}$ Uma versão desse artigo foi publicada na “The Chronicle Review”. Tradução de José Luís Oreiro.

${ }^{6}$ Schwartz Economic Growth Fellow na New America Foundation. E-mail: mail@thomaspalley.com.
} 
da produtividade, grandes déficits comerciais, inflação, perdas de emprego industrial e aumento das dívidas imobiliárias.

Os ciclos econômicos pós-1980 têm se baseado em booms financeiros e importações baratas. Os booms financeiros proporcionam o colateral necessário para suportar o aumento do endividamento que financia os gastos de consumo. $\mathrm{O}$ aumento do endividamento também tem sido suportado pela redução dos critérios de concessão de crédito e pelas inovações financeiras que permitiram um aumento do acesso ao crédito. Enquanto isso, as importações baratas têm atenuado os efeitos da estagnação salarial.

Esse padrão contrasta com os ciclos econômicos anteriores que se baseavam, não no crescimento do endividamento, mas no crescimento salarial ligado ao crescimento da produtividade e no pleno-emprego. O dispêndio, combinado com o pleno-emprego, encorajava o investimento, o que aumentava a produtividade, alimentando, assim, o crescimento dos salários.

A mudança do velho para o novo modelo de ciclo econômico foi o resultado de mudanças políticas profundas associadas à eleição de Ronald Reagan em 1980. Ela inaugurou um período no qual os negócios ascenderam e o trabalho foi rebaixado. Essa mudança foi racionalizada por economistas como Milton Friedman. O velho modelo de ciclos econômicos estava baseado numa combinação entre as inovações institucionais do New Deal, que fortaleceram os trabalhadores, e as medidas de administração da demanda agregada idealizadas pela economia keynesiana. O novo modelo de ciclo econômico se baseia em políticas que corroeram e redesenharam as instituições do New Deal, enquanto a administração da demanda foi redirecionada para a redução da inflação ao invés de assegurar o pleno-emprego. De fato, a linguagem do pleno-emprego foi descartada.

As diferenças entre os modelos de ciclo econômico posterior e anterior a 1980 podem ser facilmente ilustradas pela política. Previamente a 1980, os déficits comerciais eram vistos como um problema sério porque representavam um vazamento de dispêndio da economia o que reduzia o emprego e a produção. Desde 1980, o déficit comercial tem sido visto com um auxílio importante no controle inflacionário e também como um atenuante dos efeitos da estagnação salarial.

O novo modelo de ciclo econômico também mudou a política monetária. Previamente a 1980, a política monetária era guiada para dar suporte aos mercados de trabalho, mantendo o pleno-emprego e o crescimento dos salários, encorajando o dispêndio que induzia o investimento e o crescimento da produtividade. Agora a política monetária suporta os preços dos ativos para encorajar o endividamento, ao passo que o crescimento dos salários é visto como uma ameaça para a estabilidade da taxa de inflação.

O problema é que o paradigma pós-1980 está esgotado. Após um quarto de século tomando crédito a um ritmo frenético, muitas famílias alcançaram os seus limites de endividamento. Além disso, os preços dos ativos (especialmente as casas) se encontram em níveis elevados e com risco de cair, em alguns casos de forma bastante pronunciada. Em outras palavras, esse ciclo econômico precisa da inflação de ativos conjugada com o aumento do endividamento para impulsionar o dispêndio.

De forma mais fundamental, não está claro até agora como o crescimento poderá ser retomado em bases sustentáveis. Os consumidores não serão capazes de tomar dinheiro emprestado da mesma forma que fizeram no passado. As taxas de juros baixas provavelmente serão menos eficazes do que antes, sendo o seu efeito sobre o dispêndio similar ao de empurrar uma pedra com um barbante. Anteriormente as famílias possuíam acessos não utilizados ao crédito, os quais proporcionavam uma "base de lançamento" para a recuperação da economia. Atualmente muitas dessas famílias atingiram o limite de endividamento, bem como os bancos estão mais receosos em emprestar para tomadores arriscados.

$\mathrm{O}$ refinanciamento das hipotecas deverá ter efeitos mais fracos do que nas recessões anteriores. Em primeiro lugar, o conjunto de hipotecas com elevadas taxas de juros foi refinanciado, em larga medida, nas recessões passadas, deixando pouco espaço para o refinanciamento vantajoso de hipotecas. Em segundo lugar, a queda contínua dos preços das casas fará com que os bancos estejam menos dispostos em refinanciar as hipotecas existentes, muitas das quais podem exceder o valor de mercado das casas.

O ponto fundamental é que o modelo de ciclos econômicos pós-1980, o qual se baseava em uma combinação de inflação de ativos e elevações persistentes no endividamento das famílias, está exaurido. O problema não se restringe à perda do dinamismo econômico que esse processo proporcionava, mas também se refere à possibilidade de queda em uma espiral deflacionária se os preços dos ativos continuarem caindo e as famílias se endividarem ainda mais. Nessas circunstâncias, o Federal Reserve será incapaz de fazer alguma coisa para dinamizar o crescimento. 
Precisamos de um novo paradigma econômico que restaure o elo entre o crescimento dos salários e o crescimento da produtividade, bem como faça com que, novamente, os salários sejam a principal turbina do crescimento da demanda. Remediar a ruptura de longo prazo do elo salários-produtividade irá requerer a restauração das políticas que visem à obtenção do pleno-emprego. O pleno-emprego irá proporcionar aos trabalhadores poder de barganha. Isso irá encorajar aumentos de salário, os quais irão alimentar o dispêndio, a produtividade e o investimento. A obtenção do pleno-emprego irá requerer a coordenação entre as políticas monetária, fiscal e cambial para esse fim.

Também será necessária uma mudança no equilíbrio de poder nos mercados de trabalho. Isso irá exigir reformas e uma vigorosa fiscalização das leis do trabalho para acabar com a intimidação dos empregadores sobre os empregados no sentido de impedir estes últimos a se filiarem aos sindicatos, barganhando, assim, contratos de trabalho justos. O salário mínimo deve ser conectado com o salário médio prevalecente na economia de tal forma que o primeiro aumente à medida que a economia cresce. E o seguro desemprego deve ser ampliado e estendido.

Os Estados Unidos também devem começar a reduzir o seu déficit comercial, o qual drena dispêndio para o exterior e prejudica fortemente a indústria. Uma nova política cambial deve impedir a sobrevalorização do dólar com respeito às moedas dos principais parceiros comerciais dos Estados Unidos. Apenas um comprometimento claro e duradouro com tal política irá convencer novamente os empresários a investirem novamente na indústria americana.

Por fim, os países em desenvolvimento devem ser convencidos a abandonar suas políticas de crescimento induzido pela exportação e devem estar focados no desenvolvimento de seus mercados domésticos. No campo da política comercial, isso significa por um ponto final à concorrência internacional desleal baseada em taxas de câmbio subvalorizadas, subsídios de exportação e restrições desleais de comércio. Isso irá exigir uma nova arquitetura econômica internacional que promova o comércio leal e equilibrado - uma tarefa que irá exigir uma liderança americana altamente esclarecida.

\section{A crise econômica internacional em 2010: Uma avaliação a meio do caminho}

FERNANDO J. CARDIM DE CARVALHO

Observando-se a economia mundial em junho de 2010, pode-se dizer que há boas e más notícias, e (alguém se surpreende com isso?) uma enorme incerteza com relação ao futuro mediato.

As boas notícias referem-se, naturalmente, ao sucesso que as políticas macroeconômicas implementadas a partir do final de 2008, em quase todo o mundo, tiveram na contenção dos impactos mais destrutivos da crise financeira de 2007-2008 sobre a produção e o emprego. O produto caiu em praticamente todo o mundo (com a notável exceção de sempre, a China e sua vizinha e a Índia que sofreram apenas desacelerações de crescimento, de muito alto para alto). Em vários países desenvolvidos, a queda foi significativa, como no caso dos Estados Unidos e da Alemanha. Mas significativa como foi, ainda assim foi muito menor do que poderia ter sido, uma vez que nossos parâmetros de comparação seriam dados pela Grande Depressão dos anos 1930. A recuperação que se seguiu, por outro lado, não foi tão surpreendente, já que apoiada e alimentada pela mesma política macroeconômica que conteve a contração do produto. Políticas fiscais expansionistas em muitos países (com a notável exceção alemã), políticas monetárias de sustentação de liquidez, políticas microeconômicas de incentivo a setores específicos, mas de grande impacto, como a indústria automobilística e a de construção civil, todas contribuíram para reviver a demanda agregada e mitigar o impacto das tendências naturais de empresas e consumidores de se retrair frente ao desemprego, às incertezas do futuro, ao excessivo endividamento de alguns setores etc.

Em alguns casos, o ambiente mais favorável esconde desequilíbrios perigosos para a continuidade

${ }^{7}$ Professor titular do Instituto de Economia da Universidade Federal do Rio de Janeiro (IE/UFRJ). E-mail: fjccarvalho@uol.com.br. 
da recuperação. Certamente o caso mais ameaçador aqui é o da Alemanha, que escolheu recuperar sua economia pelo caminho do beggar thy neighbor, que tantos estragos causou na década de 1930. A estratégia alemã consistiu em baratear seus produtos de exportação (especialmente pela contração salarial, uma vez que vem, de algum tempo, perpassando inclusive governos nominalmente social-democratas, como o de Gerhard Schroeder) ao invés de ampliar sua demanda agregada. Com isso, a que voltaremos um pouco mais adiante, a recuperação alemã acabou se apoiando, pelo menos em parte, na geração de superávits em conta corrente que tem como contrapartida os déficits verificados na periferia da área euro, o chamado Club Med, composto por Grécia, Portugal, Espanha e Itália. Sem a possibilidade de se valer da política cambial e da monetária (perdidas para o Banco Central Europeu, com a criação do euro), só resta a esses países a contração fiscal. A virtude alemã é paga com o empobrecimento da periferia da área euro, o que, fatalmente, acabará se voltando contra a própria Alemanha em algum momento.

A boa notícia da recuperação do produto é temperada pela incapacidade dessas economias em diminuir o desemprego de forma significativa. Economistas liberais, que, depois do susto inicial, começam a reaparecer no cenário, explicam esse fenômeno tentando reviver noções como flexibilidade de mercados de trabalho, necessidade de se reduzir a proteção social ao trabalhador que lhe tiraria o incentivo a aceitar emprego, tentando fazer ressurgir ideias como a de que o emprego não cresce não porque falta demanda por trabalhadores, mas porque esses têm opções melhores do que trabalhar, especialmente a de "engordar ao sol", protegidos pelo seguro social. Essas ideias, que se apoiam no exótico conceito de taxa natural de desemprego, que tanto distrai os economistas de direita, liderados pelos semelhantes de Robert Lucas, e seus mais recentes clones, como John Cochrane, da vetusta e respeitável Universidade de Chicago, andaram meio sumidas por algum tempo, mas já brotam aqui e ali no debate público.

O desemprego é alto porque a demanda agregada foi sustentada pela política macroeconômica em nível suficiente para evitar colapsos do sistema produtivo, mas a ambiguidade dos governos de países como os Estados Unidos em relação às suas próprias decisões tende a reduzir sua eficácia. Certamente, o caso mais preocupante é o dos Estados Unidos. A cautela e o discurso dúplice do presidente Obama e seus auxiliares a respeito de sua política econômica são certamente mais geradores de incertezas do que incentivos à reação vigorosa. Ao mesmo tempo em que se defende, por exemplo, a extensão das medidas de sustentação fiscal da demanda (como fez recentemente no Congresso, Larry Summers, assessor mais direto do presidente), o próprio Presidente parece se intimidar com a oposição de conservadores acenando com a necessidade de cortar gastos inúteis e controlar o déficit público. Em seu histórico discurso de posse, o presidente Franklin Roosevelt afirmou audaciosamente que "first of all, let me assert my firm belief that the only thing we have to fear is fear itself". A frase, e as ações que dela decorreram, calou fundo no público americano e à audácia do Presidente o povo americano respondeu com a sua confiança e entusiasmo. A timidez e a cautela do governo atual apenas estimulam a timidez e a hesitação.

Com isso, as maiores incertezas do momento dizem respeito aos resultados das políticas empregadas até aqui. No caso americano, e em menor medida também na Europa ocidental, a maior dúvida é o que acontecerá com essas economias, uma vez que as medidas excepcionais de estímulo da demanda agregada tomadas em 2009 caduquem. A probabilidade de renovação desses estímulos não parece muito provável. Pior ainda, é que a preocupação prematura com os déficits públicos e o crescimento da dívida pública interna em países como os Estados Unidos e da Europa ocidental pode levar a uma nova contração econômica, com impactos imprevisíveis. Alguns países, como o Club Med citado antes, já estão sendo forçados a entrar por essa trilha, e essas políticas só tendem a piorar a situação, introduzindo, na verdade, novas incertezas, agora com relação, no curto e médio prazos, à estabilidade política da região, e a mais longo prazo com a sobrevivência da moeda única, que desaparecerá se o preço de sua permanência for a pobreza e o desemprego na periferia da Europa.

Nesse cenário, a melhor perspectiva parece ser a dos países emergentes, nome em código para a China, principalmente, e para aqueles de nós que corremos atrás, a uma boa distância do líder. É possível discutir a capacidade da China de manter seu intenso crescimento, especialmente se se mostrar necessário substituir a ênfase em exportações pelo apelo ao mercado doméstico, mas a suposição de que a China possa assumir a liderança da economia mundial e recuperar seu dinamismo perdido não é séria.

Com tudo isso, reforça-se a hipótese de que se segue um padrão, nos anos 2010, semelhante ao seguido nos anos 1930. Começou-se com um colapso financeiro que não apenas deu grande dramati- 
cidade aos eventos, como também gerou um enorme impacto contracionista sobre o sistema produtivo das economias atingidas. Desta vez, esses impactos foram contidos antes que reproduzissem a catástrofe dos anos 1930, mas, como naquela época, a economia mundial manteve-se frágil e volátil, com expansão aos arranques e paradas, sempre à beira da parada total em função dos eventos os mais variados. Nos anos 1930, essa situação só foi superada pelo monumental choque de demanda agregada representado pela Segunda Guerra Mundial. A possibilidade de que encontremos uma solução menor persiste, até o momento, como uma esperança, mais do que uma expectativa.

\section{Proteção natural e regulação das instituições financeiras pós-Basileia II $^{8}$}

JAN KREGEL ${ }^{9}$

Um recente Relatório de Genebra sobre a Economia Mundial, intitulado The Fundamental Principles of Financial Regulation (Brunnermeier et al., 2009), propôs uma série de medidas para tornar a liquidez sistêmica menos frequente e severa. Mais especificamente, os autores do referido Relatório propõem duas medidas:

1. Regras contábeis para expansão de funding: Os "consórcios" de recursos e ativos direcionados para funding de longo prazo têm que ser assegurados por mantenedores, cuja mensuração contábil seja transparente e não seja "marcada pelo mercado";

2. Cobrança explícita de capital para risco de liquidez: As instituições financeiras com posições de ativos de baixa liquidez e longa maturidade e fundos com ativos de curta maturidade devem incorrer em mais elevado coeficiente sobre o capital.

Ademais, o Relatório argumenta que a "confiança do sistema financeiro sobre os recursos de funding de curto prazo dos ativos de longo prazo com baixa potencialidade de liquidez de mercado tem sido a causa fundamental da instabilidade financeira”. Uma das mais críticas lições é que, enquanto estamos previamente focados na qualidade do ativo, o risco sistêmico tem muito mais relação com o fato de como os ativos são financiados. Se duas instituições possuem o mesmo tipo de ativos, porém um deles está relacionado a dívidas de longo prazo e o outro a recursos do overnight originados dos mercados monetários. Isto faz uma substancial diferença para o potencial do risco sistêmico. Assim, regras de regulação podem fazer uma ligeira distinção de como os mesmos ativos são financiados. A ausência de distinção faz com que os bancos tenham um incentivo em financiar ativos baratos. Este incentivo é mais acentuado quando a curva do rendimento esperado de um ativo possui uma inclinação ascendente em situações de boom. Tal fato explica porque houve uma confiança coletiva em ativos de curto prazo nos mercados de fundos institucionais na extensão do crash de 2007.

Será que o descasamento da maturidade dos ativos é uma questão inevitável do sistema bancário privado? Depois de tudo, não estará o sistema bancário tomando recursos de curto prazo e emprestando no longo prazo? Não necessariamente! Existem muitas exceções para se fazer uma análise generalizada e isso também é um problema de grau de escala. Pequenas empresas reclamarão que, dados os erros de garantias dos empréstimos bancários, elas não percebem terem tomado emprestado recursos de longo prazo dos bancos. Ademais, diz-se que esta situação é frequentemente observada entre os titulares de crédito que são mais sujeitos a "divorciarem-se" do que a deixar seus bancos. A realidade é que a redução da demanda de depósitos não é instantânea como ela aparenta. A taxa de declínio dos depósitos domésticos do setor privado em relação ao total das obrigações era uma medida de cresci-

\footnotetext{
${ }^{8}$ Reflexões apresentadas no Centro de Economía y Finanzas para el Desarrollo de la Argentina, Buenos Aires, em 27 de julho de 2009. Tradução de Fernando Ferrari Filho.

${ }^{9}$ Professor Senior do Levy Institute e Profesor Visitante do Center for Full Employment and Price Stability da University of Missouri-Kansas City.
} 
mento do risco de liquidez dos fundos entre os bancos. Efetivamente, "o descasamento das maturidades dos bancos pioraram através dos financiamentos das vendas por atacado” (Ibid., pp. 38-39).

Subsequentemente, Persaud (um dos autores do Relatório de Genebra) expandiu a análise para um artigo, visando mostrar como essa abordagem funcionaria ${ }^{10}$.

Segundo o autor, redistribuir risco, melhor do que tentar eliminá-lo, é a chave para fortalecer os bancos mundiais. Assim, Persaud (2009) argumenta que impor elevados requerimentos de capital não é uma panaceia para os problemas que causaram a presente crise. Esta estratégia, por si própria, reforça muito pouco o sistema financeiro porque ela não leva em consideração as diferenças entre as instituições e os tipos de risco. Ademais, para o autor, elevar os requerimentos de capital não auxilia a igualdade entre tomada de risco e capacidade de risco. Para ele, no centro da regulação moderna está a visão equivocada de que risco é uma propriedade mensurável do ativo; isto é, risco não é singular. Existem, por exemplo, risco de crédito, risco de liquidez e risco de mercado e, ademais, diferentes segmentos do sistema financeiro têm capacidade distintas de cobertura. Assim, risco tem muita relação com qual agente está mantendo o ativo e qual é o tipo de ativo. A noção - comum no congresso norte-americano - é de que existem instrumentos "seguros" para serem promovidos e instrumentos arriscados para serem desconsiderados. Alternativamente, requerimentos de capitais devem ser sensíveis à capacidade natural das instituições em relação à cobertura e aos tipos de risco que ela mantém. Ou seja, é considerado o risco de liquidez. Bancos, tradicionalmente, tomam emprestado dos depositantes que podem sacar seus recursos do overnight. Entretanto, bancos têm uma capacidade limitada de manter ativos que não podem ser rapidamente vendidos sem ter uma elevada taxa de desconto. Assim sendo, faz sentido requerer capital extra para deixar de lado quaisquer ativos que carreguem riscos de liquidez. Tal risco é mais seguro para ser mantido pelos fundos de pensão e companhias de seguro, pois eles têm funding provenientes tanto dos aposentados quanto dos prêmios de sinistros, que geralmente não se "evaporam" no overnight.

Ademais, bancos podem ter, efetivamente, posições cobertas contra risco de crédito através da diversificação de seus empréstimos e da utilização do conjunto de informações que eles têm acerca dos potenciais tomadores de recursos. Fundos de pensão são menos capazes de compensarem riscos de crédito. Seus funding de longo prazo não auxiliam, pois quanto maior o período de maturação do investimento, maior o período para que haja um default.

O caminho para tornar o sistema financeiro seguro é criar mecanismos para que os diferentes graus de risco de uma instituição sejam direcionados para uma situação de capacidade de cobertura. A "regulação" moderna fez o oposto. Ao requerer que os bancos deixassem de lado mais capital para riscos de crédito do que as instituições não bancárias, os reguladores passaram a encorajar não intencionalmente os bancos a mudarem seus riscos de crédito para aqueles que buscavam uma renda extra, mas que tinham capacidade limitada para cobrir este tipo de risco. Ao não requerer que os bancos disponibilizem capitais extras para cobrir o descasamento da maturidade do investimento, eles encorajaram os bancos a aceitarem riscos de liquidez que não poderiam compensar. Ademais, ao suportarem as valorizações dos ativos "marcados a mercado" (nos quais fazem as instituições manter os valores aos seus preços correntes) e os requerimentos de solvência de curto prazo, os reguladores desencorajaram os emissores e fundos de pensão de tomarem riscos de liquidez que, até então, eram apropriados para eles.

Por que isto foi feito? O objetivo da regulação financeira não seria perseguir e eliminar risco. Tampouco o objetivo seria acumular e proteger o capital, para "somente nos deixar com os bancos gigantes”. Ao contrário, seria necessário diferenciar menos as instituições pelas quais elas são chamadas e mais pelas quais elas são financiadas

Isto parece ser uma proposta razoável à la Minsky; porém a análise de Minsky sobre fragilidade financeira e bancária sugere que ela pode conter um obstáculo maior. Conforme Minsky (1977, pp. 8-9 e 17) ${ }^{11}$ : "Instituições financeiras, com expectativas de negócios, tomam emprestado e dinamizam instrumentos financeiros. Ao fazerem isso, suas obrigações têm que ser consideradas mais seguras ou mais convenientes para os proprietários de riqueza do que seus ativos. Usualmente, isso sinaliza que seus ativos de longo prazo são superiores às obrigações e às várias margens de segurança de provisões das

\footnotetext{
10 "How to save the financial system”, Business Week, June 18, 2009.

11 "Banking and a fragile financial environment", Journal of Portfolio Management, Summer, 1977.
} 
organizações financeiras [...] Um banqueiro manipula os recursos da população em conformidade com seus próprios recursos. $\mathrm{O}$ inverso da relação ativos/valor contábil, razão valor contábil/ativo mostra como os recursos do banco estão sendo investido juntamente com os recursos da população em geral e como os banqueiros operacionalizam seus negócios. A relação valor contábil/ativos é análoga à margem de requerimento imposta sobre as transações no mercado acionário [...] Bancos comerciais e outras instituições financeiras estão inseridas em finanças especulativas: o grau de maturidade de suas dívidas são menores que o grau de maturidade de seus ativos. Eles necessitam, continuamente, atrair depósitos e vender obrigações para serem capazes de assegurar as retiradas de recursos. Sendo suas dívidas [dos bancos e instituições financeiras] de curto prazo, significa que eles são vulneráveis ao desenvolvimento operacional do mercado financeiro. Ademais, mesmo que os ativos dos bancos de longo prazo sejam maiores que suas obrigações, seus ativos são mais de curto prazo do que o volume de capital e os ativos financeiros pertencentes a unidades que estão financiando o banco. Assim, quanto maior o peso dos bancos e dos intermediários financeiros na economia, maior será o peso do financiamento especulativo nos financiamentos das firmas e dos consumidores. Não somente os bancos engajam-se em financiamentos especulativos, mas eles induzem os financiamentos especulativos para outros".

Logo, do ponto de vista minskiano, a proposta de Persaud (2009) que relaciona os requerimentos de capital ao grau de descasamento da maturidade de ativos visa à induzir os bancos a adotarem um financiamento hedge para seus ativos. Entretanto, isto reduziria a lucratividade bancária pela diferença entre a liquidez de seus ativos e suas dívidas. Como Minsky argumenta, a equação do lucro pode ser $\mathrm{P} / \mathrm{B}=\{\mathrm{P} / \mathrm{A}\} \quad\{\mathrm{A} / \mathrm{B}\}$, onde $\mathrm{P}$ são os lucros, $\mathrm{B}$ é o valor contratado das ações dos proprietários e $\mathrm{A}$ é o portfólio de ativos do banco. De outra forma, ROE=POA, que é a alavancagem. A limitação da alavancagem, por sua vez, limitaria a capacidade dos bancos em financiar seus ativos com obrigações de maior liquidez. Esta redução da liquidez reduziria a ROA (retorno sobre ativos) dos bancos. Em um ambiente de competição, mesmo com uma limitação estrita das atividades permitidas, isto levaria os bancos a buscar maiores alavancagens para preservar o ROE (retorno sobre patrimônio líquido).

A proposta também gera implicações para as decisões relativas às preferências relativas aos sistemas bancários segmentados e às holding financeiras ou ainda às estruturas bancárias universais de tipo europeu. De acordo com as propostas contidas no Relatório de Genebra, as instituições financeiras seriam taxadas e estariam limitadas a manter e negociar os ativos financeiros que lhes proporcionassem vantagens naturais de financiamento adequadas a seus ativos. Isto significa que haveria uma segmentação no sistema, com uma variedade de tipos de atividade e instituições financeiras determinadas pela posição natural de funding e incentivadas pelas taxações preferenciais sobre os ativos. Presumivelmente, isto excluiria a formação de holdings financeiras, a menos que fossem criadas barreiras chinesas impenetráveis para separar as unidades, determinadas por seus recursos "naturais" de funding.

Isto vincula a proposta do Relatório de Genebra de marcar os valores dos ativos às fontes de funding e de avaliar os coeficientes de capital de acordo com o grau de cobertura natural provido pelo funding natural. No entanto, isso parece não fornecer uma compreensão adequada sobre a forma como os bancos e outras instituições financeiras criam valor e obtêm lucro. Como mencionado anteriormente, do ponto de vista de Minsky, os bancos obtêm lucros através da diferença entre a liquidez de suas dívidas e de seus ativos, e não pelo teor ou pela maturidade de tais ativos. O ponto essencial é saber como os bancos conseguem liquidez para suas dívidas. Aqui, é importante a ideia de Minsky sobre as margens de segurança, ativos segurados com alta liquidez para garantir que sempre possam cumprir suas obrigações. Mais uma vez, o teor dos ativos não é tão importante quanto o mercado no qual estes ativos podem ser vendidos para prover liquidez. Os mercados aprenderam com as crises de Bear Stearns e Lehman and Borthers e sabem que mesmo os ativos de curto prazo e livres de risco podem não ter liquidez.

Ademais, parte da liquidez das dívidas das instituições financeiras pode ser estabelecida através do modo como os riscos são cobertos, ou seja, através da eficiência de sua estratégia de hedge, mais do que se a cobertura é natural. Em suma, é importante observar a forma como os bancos cobrem seus riscos e como a regulação pode ser vista como uma imposição de cobertura ${ }^{12}$. O requerimento de capital é um método muito ineficiente para impor cobertura aos bancos. De fato, estes tendem a fazer justamente o contrário. A regulação deveria incentivar os bancos a aplicarem coberturas apropriadas da melhor forma possível. Isto gera um aumento no ROA e reduz os incentivos para aumentar a alavancagem.

\footnotetext{
${ }^{12}$ Kregel, J. Past and Future of Banks, Ente per gli Studi Monetari, Bancari e Finanziari Luigi Einaudi, Quaderni di Ricerche, n² 21, Bancaria Editrice, Rome, 1998, capítulo 7.
} 


\section{Dívida grega: calote ou reestruturação?}

Depois da Grécia, o quê? A Hungria? Ou as perspectivas de baixo crescimento para a Europa? Ou a decepção com a retomada norte-americana? Ou, ainda a Grécia? Os mercados financeiros internacionais são sempre nervosos e instáveis - tristes em alguns momentos, eufóricos em outros, mas sempre em meio a uma dialética de racionalidade e irracionalidade. Nós, economistas, ainda que com um ar mais "científico", cometemos os mesmos pecados. Diante disso, políticos e empresários — os agentes na economia real - perplexos, não sabem o que fazer. Investir ou não investir? Continuar com a política fiscal expansionista, ou está na hora de cuidar da dívida pública elevada de cada Estado e da dívida externa eventualmente elevada de cada país? E perguntam: estaria a crise em forma de $\mathrm{W}$ começando?

Com o problema da Grécia houve de fato uma ameaça de a crise retornar com força. A demora da Alemanha contribuiu para agravar o problema. Entretanto, afinal o Banco Central Europeu (BCE) e aquele país fizeram o que se esperava deles, garantiram a dívida da Grécia e, mais amplamente, a dívida dos demais países do euro e, embora não ficasse tudo resolvido, a crise amainou. Todos sabem que, estruturalmente, o problema da Grécia não está resolvido, porque, mesmo que cumpra fielmente seu programa de ajuste fiscal e seu PIB caia cerca de 3\% a $4 \%$ nos dois próximos anos, no final desses dois anos, sua dívida pública em relação ao PIB ainda será de $150 \%$.

Diante de um quadro desse tipo, volta a pergunta sobre uma possível saída da Grécia do euro, mas isto é muito pouco provável. A vantagem de ter uma moeda que começaria sua história já desvalorizada em relação ao euro não compensa os riscos de ficar fora da proteção do sistema euro. Existe, entretanto, a possibilidade de reestruturar a dívida pública dentro do euro. É a melhor coisa que a Grécia teria a fazer dado que sua situação é de insolvência, pois mesmo que a taxa de juros sobre seus títulos volte a níveis razoáveis e nesse nível se estabilize, ela não terá condições de honrar seus compromissos financeiros e voltar a crescer.

Mas um leitor poderia me perguntar: o senhor então está propondo um "calote"? Não, meu amigo, estou sugerindo que a Grécia faça uma "reestruturação" com desconto. Que é a mesma coisa que um calote e algo muito diferente. É a mesma coisa porque para o credor o resultado é o mesmo: recebe apenas parte de seu crédito. É muito diferente, porque na expressão calote existe um tom pejorativo que sugere um devedor irresponsável. A reestruturação tem uma conotação mais amena, porque reparte a culpa entre o devedor e os credores e, principalmente, porque afinal todos ou a grande maioria compreendem que era a única solução racional para o problema dada a insolvência do Estado grego.

Quando uma crise de dívida soberana é resolvida por um "calote" ela é geralmente mal resolvida porque isso significa que não havia insolvência, ou que os mercados financeiros não aceitaram o diagnóstico de insolvência do país devedor, e julgam que ele agiu de má fé. Quando temos uma reestruturação, embora ela seja em princípio unilateral ou quase unilateral, o problema se resolve muito melhor, porque, afinal, o que ela faz é sancionar uma perda dos credores que mercados financeiros razoavelmente eficientes já devem ter antecipado pela precificação dos créditos com desconto.

Os governos de países cujo Estado se tornou insolvente têm medo de fazer uma reestruturação porque temem que seja vista como calote. Compreendo esse medo. Os mercados financeiros, os governos dos países ricos e o Fundo Monetário Internacional fazem sempre o que se espera do "establishment": pressionam para que o país faça o ajuste ao invés de reestruturar a dívida. E sempre ameaçam que a ação será considerada um calote e que, afinal, o país será obrigado a se curvar dada a força dos credores ou a da lei internacional.

Se o quadro não for de insolvência, mas de liquidez — de mero desequilíbrio entre vencimentos e receitas - essas ameaças poderão valer. No caso, porém, como é o da Grécia hoje, em que o quadro de insolvência esteja claro, essas ameaças são antes retóricas do que reais. Os mercados financeiros sabem que a reestruturação é necessária. Sabem porque seus economistas e seus operadores viram os números e sabem o que eles significam. Sabem também porque economistas, como Martin Wolf, e publicações econômicas que eles respeitam, como, por exemplo, The Economist, afirmaram que essa será provavelmente

${ }^{13}$ Professor emérito da Fundação Getúlio Vargas (FGV-SP). E-mail: lcbresser@uol.com.br. 
a solução mais adequada para a crise grega. Esses economistas e essas publicações constituem uma espécie de "opinião pública" financeira, que, como toda opinião pública, pode estar errada, mas não é o que importa; o importante é que ações realizadas de acordo com ela ganham legitimidade imediata.

Não há razão para o mundo voltar a mergulhar na crise. Ela ainda custa muito caro aos países ricos, mas foi bem enfrentada por seus governos e suas economias estão a caminho da recuperação. No percurso, crises como a da Grécia podem ocorrer, mas se seu governo tiver a coragem e a determinação de fazer o que precisa ser feito, os demais governos e o próprio mercado financeiro compreenderão, tal que esse foco de crise estará brevemente neutralizado, ao invés de ficar supurando por muito tempo.

\section{A crise na Europa e os dilemas da Espanha}

JOSÉ LUIS OREIRO ${ }^{14}$

A moeda comum europeia, o Euro, foi implantada em 1999 como mais uma etapa no que se entendia como um processo que deveria conduzir o Velho Continente a tão sonhada unificação política, a qual, por sua vez, era vista por muitos europeus como condição necessária para a Europa reassumir sua liderança histórica no mundo, suplantando os Estados Unidos. Passados mais de 10 anos da introdução do Euro surgem dúvidas cada vez maiores sobre a sustentabilidade da moeda comum a médioprazo.

Os países que compõe a área do Euro são bastante heterogêneos no que se refere tanto à sua competitividade externa como à sua situação fiscal. Essas diferenças impõem limites bastante estreitos para a condução de políticas anticíclicas "autônomas” por parte dos países da área do Euro.

Nesse contexto, podemos identificar dois grupos de países. No primeiro grupo, composto basicamente pela Alemanha, o crescimento do PIB é liderado pelas exportações, a taxa real de câmbio permanece em patamares razoavelmente competitivos e a situação fiscal (medida pela relação dívida/PIB e déficit público/PIB) permite o uso moderado da política fiscal por vários anos como instrumento de política anticíclica. Em um contexto de forte apreciação do Euro frente ao dólar e outras moedas, a competitividade externa da economia alemã foi mantida nos últimos 10 anos graças a uma política de "moderação salarial" adotada pelos sindicatos alemães, os quais, em troca da manutenção dos empregos industriais na Alemanha, aceitaram que um crescimento do salário real muito abaixo da produtividade do trabalho. Essa política salarial permitiu uma queda acentuada do custo unitário do trabalho na Alemanha relativamente aos demais países da área do Euro, viabilizando a manutenção da competitividade da economia alemã e a importância da indústria e das exportações como motor do crescimento de longo prazo da maior economia da Europa.

O segundo grupo de países é constituído pelos PIIGS: Portugal, Itália, Irlanda, Grécia e Espanha. Em que pesem a existência de algumas diferenças entre os referidos países, podemos destacar a presença de alguns traços comuns a esse grupo de países. Com efeito, esses países sofrem de um problema crônico de competitividade externa, o qual se reflete em grandes déficits em conta-corrente (no caso da Espanha quase $10 \%$ do PIB em 2008) somado com desequilíbrios fiscais que variam de moderado (no caso da Espanha) à gravíssimo (o caso da Grécia). O regime de crescimento desses países nos últimos anos foi, em larga medida, finance-led, ou seja, liderado pelo aumento do consumo (e do investimento imobiliário) financiado com endividamento privado e aumento dos preços dos ativos. A combinação entre desequilíbrios nos balanços do setor privado e desequilíbrios nas contas públicas não só torna muito estreito o espaço para a utilização da política fiscal de forma anticíclica, como ainda inviabiliza as chances de uma recuperação do nível de atividade por intermédio de um aumento da demanda doméstica privada. Dessa forma, a única saída que esses países têm para a atual crise consiste em um aumento forte e sustentável das exportações, o qual, no entanto, fica no aguardo da recuperação da economia mundial, uma vez que: (i) a adesão ao Euro eliminou a possibilidade de se usar a desvalorização do câmbio como instrumento de política econômica; e (ii) os sindicatos desses países não têm a

${ }^{14}$ Professor do Departamento de Economia da Universidade de Brasília. E-mail: joreiro@unb.br. 
mesma "visão estratégica" dos sindicatos alemães e aparentemente não estão dispostos a trocar redução de salário real por garantia de manutenção de emprego no presente e no futuro. Sendo assim, os países desse grupo não têm como promover um ajuste rápido de sua competitividade externa, o que deverá mantê-los por um período longo de tempo numa situação de estagnação econômica.

A crise recente da Grécia expôs as fragilidades da área do Euro. Em função das desconfianças crescentes dos mercados financeiros a respeito da solvência do setor público na Grécia, as taxas de juros dos títulos da dívida pública desse país aumentaram consideravelmente nos últimos meses o que terminou por agravar a situação fiscal gregas, criando um ciclo vicioso: piora das expectativas do mercado financeiro levando a um aumento das taxas de juros que, por sua vez, gera um agravamento da situação fiscal, conduzindo a uma nova piora das expectativas do mercado financeiro. Como no contexto do arranjo monetário prevalecente hoje na área do Euro o governo da Grécia não pode contar com o apoio financeiro do Banco Central Europeu para monetizar, ao menos uma parte, do seu enorme déficit fiscal, segue-se que a eliminação desse ciclo vicioso exige um ajuste fiscal draconiano por parte do governo grego, justamente no momento em que a política adequada, por conta do quadro recessivo que vive o país, e da ausência de outros instrumentos de política econômica, é a manutenção dos déficits fiscais. A Grécia encontra-se, portanto, entre a Cruz e a Espada: se não fizer um ajuste fiscal forte e crível, os mercados financeiros internacionais irão exigir taxas de juros cada vez mais altas para o financiamento do seu déficit fiscal, o que irá conduzir o País inexoravelmente ao default; se fizer o ajuste fiscal requerido pelos mercados, poderá obter um alívio nas condições de financiamento do seu déficit público às custas de um aumento significativo do desemprego e queda do nível de atividade econômica. Nessas condições, a sociedade e os políticos da Grécia podem, em algum momento, perceber que os custos de manutenção do País na área do Euro superam os seus benefícios, o que levará a Grécia a abandonar a moeda comum. Se isso acontecer, a pressão sobre os demais PIIGS, principalmente a Espanha, pode se tornar insuportável, levando a um efeito cascata de saída de países da área do Euro.

Com efeito, a Espanha, a quarta maior economia da área do Euro - com um PIB de US\$ 1,6 trilhão - foi profundamente afetada pela crise econômica mundial. A taxa de desemprego passou de $8,2 \%$ da força de trabalho em 2007 para $11,3 \%$ em 2008, fechando 2009 em torno de $20 \%$. O PIB espanhol apresentou uma contração de 3,6\% em 2009 e as expectativas do FMI para 2010 são de uma nova contração de $0,7 \%$.

A performance da economia espanhola nos últimos anos teve também um profundo impacto sobre a sua situação fiscal. Até 2007, a Espanha vinha reduzindo a dívida pública como proporção do PIB. Com efeito, entre 2004 e 2007 a dívida pública apresentou uma expressiva redução, caindo de $48 \%$ para $38 \%$ do PIB. Ou seja, a Espanha, ao contrário dos demais PIIGS, não estava fazendo uma "farra fiscal"; pelo contrário, a gestão fiscal da Espanha era sólida e responsável, condizente com os "princípios básicos da ortodoxia”. Após 2007, contudo, a dívida pública passa a apresentar uma elevação expressiva, alcançando o patamar de $70 \%$ do PIB no início de 2010. Essa deterioração resultou das diversas medidas de estímulo fiscal que o governo do primeiro-ministro José Luiz Zapatero vem adotando desde 2008 para estimular a combalida economia espanhola e para evitar que a recessão se transformasse numa depressão. Como consequência dessas medidas e da própria recessão, o déficit orçamentário espanhol foi de $11,9 \%$ do PIB em 2009.

A deterioração do quadro fiscal da Espanha tem levado os mercados financeiros a temer um calote por parte do governo espanhol. Os mercados pressionam o governo da Espanha para adotar rapidamente medidas no sentido de reduzir o déficit fiscal. Em função dessas pressões, o governo da Espanha já sinalizou sua intenção de cortar gastos e aumentar impostos, de forma a reduzir o déficit orçamentário para 3\% do PIB até 2013. Mas será essa política a mais adequada para a Espanha sair da crise na qual se encontra?

Fazer um ajuste fiscal dessa magnitude, em um prazo relativamente curto de tempo e considerando o contexto de que a Espanha apresenta elevada taxa de desemprego e grande ociosidade da capacidade produtiva, não parece ser uma política muito sensata. Isso porque o ajuste fiscal implica uma contração da demanda do setor público (ou, analogamente, num aumento da poupança do setor público) e a economia espanhola precisa de mais demanda, e não menos, para se recuperar. Além disso, nos próximos anos o setor privado espanhol, atolado em dívidas que superam, em muito, a dívida do setor público, terá que reduzir o seu nível de dispêndio para tentar ajustar os seus balanços. Com efeito, o endividamento do setor privado (empresas e famílias) era de cerca de 4,1 trilhões de dólares no final de 2008 segundo dados da McKinsey Global Institute, quase três vezes o valor do PIB da Espanha. Esse 
enorme endividamento do setor privado irá exigir uma redução muito forte do dispêndio das famílias e das empresas da Espanha. Dessa forma, os gastos de consumo e de investimento do setor privado deverão permanecer estagnados por vários anos. Em outras palavras, a poupança privada (soma das poupanças das famílias e das empresas) terá que aumentar muito nos próximos anos para reduzir o enorme endividamento do setor privado.

Em face do aumento necessário da poupança privada, a recuperação da economia espanhola exige ou uma redução da poupança pública - política que vem sendo adotada até o presente momento pelo governo espanhol - e/ou uma redução da poupança externa, ou seja, um aumento do saldo em conta-corrente. O espaço para a utilização da política fiscal para estimular a economia está rapidamente chegando ao fim. Embora países como a Itália tenham uma dívida pública como proporção do PIB muito maior que a Espanha, o ritmo de deterioração fiscal da Espanha é assustador. Se essa velocidade for mantida, em poucos anos a dívida pública da Espanha irá superar 100\% do PIB. Não é demais salientar que, recentemente, os mercados sinalizaram que não estão dispostos a tolerar uma deterioração muito mais forte da situação fiscal da Espanha.

Isso deixa a Espanha com uma única solução possível: reduzir a poupança externa, ou seja, cortar o seu gigantesco déficit em conta-corrente. Entre 2003 e 2008 a Espanha vivenciou uma explosão do seu déficit em conta-corrente, o qual saltou de 30,8 bilhões de dólares em 2003 para 154,1 bilhões de dólares em 2008, o que equivale a quase $10 \%$ PIB. O aumento do déficit em conta-corrente resultou, em larga medida, do aumento do déficit comercial espanhol, o qual passou de 45,1 bilhões de dólares em 2003 para 129,6 bilhões de dólares em 2008.

Se a Espanha não estivesse na área do Euro, a solução seria simples: bastaria uma forte desvalorização da taxa de câmbio, para impulsionar as exportações, contrair as importações e aumentar as receitas com o turismo. O problema é que a adesão à moeda única europeia tirou a possibilidade de usar a taxa de câmbio como instrumento de política econômica.

Então como a Espanha pode sair desse imbróglio? Existem duas alternativas possíveis. A primeira é produzir um ajuste na competitividade da economia espanhola por intermédio, não de uma desvalorização do câmbio, mas de uma queda dos salários. A redução dos salários teria o efeito de produzir um aumento da relação câmbio/salário, reduzindo, assim, os custos das empresas espanholas em euros, o que teria o mesmo efeito de uma desvalorização do câmbio, caso a peseta ainda fosse a moeda corrente da Espanha. O problema com essa saída é que a sua implementação irá contar com a fúria dos sindicatos espanhóis, o que certamente torna muito custosa essa alternativa.

A segunda alternativa é o abandono puro e simples do Euro. Nesse cenário, a Espanha volta a ter uma moeda corrente própria e poderá desvalorizar o câmbio para incentivar as suas exportações. Os custos dessa alternativa também serão elevados. Certamente haverá corridas aos bancos, fuga de capitais e moratória de todos os contratos em euros no País. A adoção dessas medidas exigirá que a Espanha adote fortes controles a saída de capitais, os depósitos a vista terão que ser parcialmente congelados e o governo deverá intervir nos contratos de dívida em euros para arbitrar ganhos e perdas entre as partes.

\section{O efeito-contágio da crise global sobre os países emergentes}

DANIELA MAGALHÃES PRATES ${ }^{15}$

No primeiro semestre de 2008, a crise financeira iniciada em meados de 2007 no centro do sistema, os Estados Unidos (especificamente, no mercado de hipotecas subprime), começou a se espraiar para alguns países emergentes, mas, somente em meados de setembro, quando ela se converteu num fenômeno sistêmico (após a falência do banco de investimento Lehman Brothers), observou-se seu transbordamento praticamente generalizado para esses países, cujas empresas e bancos não tinham nenhum vínculo com os títulos vinculados àquelas hipotecas.

${ }^{15}$ Professora do Instituto de Economia da Unicamp. E-mail: danimagaprates@gmail.com. 
O efeito-contágio da crise sobre as regiões emergentes ocorreu mediante vários canais de transmissão - que derivam das múltiplas relações de interdependência entre as economias emergentes e avançadas - envolvendo seja a conta corrente (queda dos preços das commodities e da demanda mundial e aumento das remessas de lucros pelas empresas e bancos), seja a conta financeira (menor ingresso de investimento direto, saída dos investimentos de portfólio, interrupção das linhas de crédito comercial e forte contração dos empréstimos bancários). Assim, não se confirmou a hipótese do "descolamento" (decoupling), defendida por vários analistas — segundo a qual os países emergentes asiáticos e latino-americanos, com situação externa e fiscal favorável, elevadas reservas cambiais e inflação sob controle, seriam capazes de sustentar seu dinamismo econômico após a eclosão da crise.

Os defensores dessa hipótese desconsideraram não somente a existência dessas múltiplas relações, mas também a natureza hierárquica e assimétrica do sistema monetário e financeiro internacional (SMFI). A assimetria monetária refere-se, exatamente, à dimensão hierárquica do sistema monetário internacional. Nesse sistema, as divisas se posicionam de forma hierárquica, de acordo com seu grau de conversibilidade, que diz respeito à sua capacidade de desempenhar em âmbito internacional as três funções da moeda: meio de pagamento, unidade de conta e de denominação dos contratos e ativo de reserva. O dólar, a divisa-chave, situa-se no topo da hierarquia, pois tem o maior grau de conversibilidade. Em uma posição intermediária encontram-se as moedas emitidas pelos demais países centrais, denominadas de divisas conversíveis, já que são utilizadas, de forma secundária, como meio de denominação dos contratos em âmbito internacional e demandadas como ativo de reserva pelos investidores estrangeiros. No espectro oposto, estão as moedas emitidas pelos países emergentes, que são as divisas inconversíveis, pois são incapazes de desempenhar, mesmo de forma secundária ou marginal, essas funções.

À assimetria do sistema monetário internacional sobrepõe-se a assimetria do sistema financeiro internacional, a qual possui duas dimensões. A primeira refere-se aos determinantes dos fluxos de capitais direcionados aos países emergentes. Esses fluxos dependem, em última instância, de uma dinâmica exógena a esses países, que estão permanentemente vulneráveis à sua reversão, decorrente tanto de mudanças na fase do ciclo econômico e/ou na política monetária dos países centrais, como do aumento da preferência pela liquidez dos investidores globais. A segunda dimensão da assimetria financeira diz respeito à inserção marginal destes países periféricos emergentes nos fluxos de capitais globais. Apesar do crescimento da participação dos ativos emitidos por esses países nos portfólios dos investidores residentes nas economias centrais ao longo dos anos 1990, essa participação ainda é residual.

As assimetrias monetária e financeira, que se auto-reforçam, têm três importantes desdobramentos para a dinâmica dos mercados de câmbio dos países emergentes. Em primeiro lugar, esses mercados são especialmente vulneráveis à volatilidade intrínseca dos fluxos de capitais, pois estes são determinados, em última instância, por uma dinâmica exógena. Nos momentos de reversão do ciclo, de mudanças na política monetária no centro ou de aumento da preferência pela liquidez, os ativos financeiros “emergentes”, por não desempenharem a função de reserva de valor e, assim, não cumprirem o papel de "receptáculo" da incerteza em âmbito mundial, são os primeiros alvos dos movimentos de "fuga para a qualidade" dos investidores globais.

Em segundo lugar, o fato de uma proporção marginal dos fluxos ser alocada nos países emergentes contribui, igualmente, para a maior volatilidade dos seus mercados de câmbio. Em outras palavras, estes países são price-takers. Isto porque, se, de forma geral, a instabilidade das aplicações é maior no caso dos ativos estrangeiros em relação aos nacionais (ou seja, os investidores tendem a resgatar de forma mais frequente as aplicações em ativos externos), no caso dos ativos "emergentes", essa instabilidade é ainda maior dados os impactos igualmente marginais da venda desses ativos sobre a rentabilidade dos portfólios globais. Em terceiro lugar, a despeito da natureza residual dos fluxos de capitais direcionados para os países emergentes, os efeitos potencialmente desestabilizadores desses fluxos sobre os mercados de câmbio e financeiros domésticos são significativos, uma vez que, em relação ao tamanho desses mercados, o volume alocado pelos investidores globais não é marginal.

Os desdobramentos adversos das assimetrias do SMFI resumidos acima ficaram evidentes no momento mais agudo da crise - especificadamente, do dia 15/09/2008 ao final de 2008 - , quando o movimento de fuga para a qualidade teve efeitos muito mais desestabilizadores sobre os mercados de câmbio dos países emergentes. Considerando uma ampla amostra de economias avançadas e emergentes, no último trimestre de 2008, enquanto as moedas emergentes depreciaram, em média, 9,9\% ante o dólar, as moedas dos países avançados apreciaram 12,7\%, também ante o dólar. Nesse momento, nem mesmo economias emergentes com fundamentos macroeconômicos considerados sólidos ficaram incólumes ao efeito-contágio da crise.

Finalmente, vale mencionar que, se, no momento mais agudo da crise, o efeito-contágio da crise atingiu todas as moedas emergentes de forma praticamente indiscriminada, independentemente dos 
chamados fundamentos (em função do seu denominador comum, sua posição subordinada no SMFI), ao longo de 2009 a situação das transações correntes e das contas públicas e a proporção do endividamento externo ou doméstico em moeda estrangeira condicionaram não somente as trajetórias das taxas de câmbio, mas também o raio de manobra e a eficácia das políticas macroeconômicas anticíclicas.

\section{Como o Brasil superou a crise}

JULIO GOMES DE ALMEIDA ${ }^{16}$

O declínio de 0,2\% do PIB brasileiro em 2009 foi indicativo da força de uma economia que, a despeito de ter acionado poucos mecanismos anticíclicos relativamente a outros países, evitou uma recessão mais profunda. Na base do êxito do Brasil em lidar com a maior crise desde a Grande Depressão de 1929 estão a remoção da vulnerabilidade externa mediante a acumulação de reservas que às vésperas da crise chegavam a quase US $\$ 200$ bilhões, a maior solidez das contas públicas e do endividamento do setor público e a contaminação zero das instituições financeiras do País com os ativos "tóxicos" que notabilizaram o boom financeiro internacional e que sofreriam forte desvalorização com a crise

Foi também relevante a aplicação de políticas anticíclicas pelo poder público. Mas, no que diz respeito ao esforço fiscal que tanta importância teve no enfrentamento da crise pelos países de economia desenvolvida e destacados países em desenvolvimento, este limitou-se, no caso brasileiro talvez, a $1 \%$ do PIB, por renúncia de impostos do governo federal na compra de bens duráveis como automóveis, materiais de construção, linha branca e móveis, e atrasos de recebimentos que fizeram do governo um financiador de última instância para empresas com dificuldades de acesso ao crédito.

Por outro lado, a redução de juros entrou em cena muito tarde. Apenas em janeiro de 2009 ocorreu a primeira redução da taxa básica, enquanto o agravamento da crise externa teve lugar, de forma dramática, em setembro de 2008. A taxa Selic cairia de $13,75 \%$ ao ano para $8,75 \%$ ao ano entre janeiro e julho de 2009. Como há um intervalo de tempo entre a queda da taxa básica de juros e seus efeitos na atividade real, provavelmente a política de juros acelerou a recuperação da economia quando esta já estava em curso, vale dizer, em meados de 2009, sem ter sido em si um antídoto à crise ou um mecanismo primário promotor da reativação.

O governo lançaria mão de medidas de aumento da liquidez na economia, com a liberação entre fins de setembro de 2008 e início de 2009 de $\mathrm{R} \$ 100$ bilhões que antes os bancos recolhiam compulsoriamente ao Banco Central. Juntamente com uma ação deliberada de política bancária para evitar uma crise nos bancos de menor porte, na qual instituições públicas adquiriram participações e compraram carteiras de crédito de bancos em dificuldades, a medida de aumento de liquidez foi relevante, pois abortou a possibilidade de corrida bancária ou de dúvidas sobre a situação de liquidez dos bancos brasileiros.

Estes vinham promovendo uma enorme evolução do crédito para pessoas físicas e, sobretudo, para pessoas jurídicas, tendo por base em ambos os casos o alargamento dos prazos dos financiamentos, sem contrapartida de ampliação de prazos do lado da captação de recursos. Para se ter ideia do boom de crédito que se desenvolvia na economia no momento anterior à crise internacional, basta observar que em setembro de 2008 o crédito crescia 45,0\% e 17,9\%, respectivamente, para pessoas jurídicas e pessoas físicas, na comparação com o mesmo mês do ano anterior.

Dada a onda de dúvidas e incertezas que se instaurou quando explodiu a crise internacional, esse intenso crescimento dos financiamentos e o descasamento de prazos que o acompanhava, transformaram-se em fatores de elevação do risco dos bancos mais alavancados e expostos a captações no interbancário e junto a fundos de investimentos e a grandes empresas. A incerteza se agravaria à medida que iam se tornando públicos os elevados montantes de empréstimos a empresas concedidos em operações casadas com aplicações em mercados futuros de câmbio nas quais as empresas assumiram riscos cambiais. Com a desvalorização do real foram gerados vultosos prejuízos em muitas empresas brasileiras, o que em setores como celulose, alimentos processados e açúcar e álcool levou a quebras de empresas nacionais de porte. No contexto internacional adverso que afugentava potenciais compradores estran-

${ }^{16}$ Professor do IE/Unicamp. E-mail: jsgalmeida@uol.com.br. 
geiros e dado um apoio financeiro redobrado concedido pela agência brasileira de financiamento, o BNDES, os grandes grupos nacionais foram os principais absorvedores das empresas em crise.

A propósito, o apoio financeiro do BNDES também foi relevante para viabilizar a compra de empresas no exterior por parte de empresas nacionais e por financiar absorções ou associações entre empresas nacionais. Com isso, em vários segmentos da atividade econômica emergiram da crise grupos nacionais com muito maior porte e poderio financeiro. Essa consequência da crise poderá vir a condicionar positivamente em um futuro próximo a inserção de empresas brasileiras no exterior e sua capacidade inovadora, dois traços que as empresas nacionais, sabidamente, deixam a desejar.

As medidas na área de liquidez e de política bancária, portanto, evitaram uma crise de liquidez que, se desencadeada, restringiria de forma aguda o crédito e tornaria inevitável uma recessão de grandes proporções na economia. Um instrumento importante para a recuperação da capacidade de concessão de novos financiamentos por parte dos bancos de menor porte foi a garantia concedida pelo Fundo Garantidor de Crédito aos depósitos a prazo emitidos por esses bancos.

A medida anticíclica mais destacada do nosso ponto de vista não veio nem da área fiscal, nem da política monetária ou de liquidez, a despeito da inegável relevância de cada uma delas. Veio, sim, da orientação que o governo transmitiu aos seus bancos (Banco do Brasil, Caixa Econômica Federal e BNDES) para que ampliassem seus financiamentos. No início da crise o crédito dos bancos públicos representava cerca de $35 \%$ do crédito total, percentual que subiria a $41 \%$ (percentual de fevereiro de 2010). No contexto em que os bancos privados contraíam os seus financiamentos, foi esse espaço ocupado pelos bancos públicos o determinante por não ter havido na economia uma crise de crédito entendida esta não somente como a contração do volume de financiamentos concedidos, mas também como uma onda de falências de empresas e de liquidação de ativos. O crédito se retraiu de fato, o que trouxe consequências negativas para a atividade econômica, mas logo pôde ser recomposto, como veremos em seguida.

Nos casos do Banco do Brasil e Caixa Econômica Federal, a orientação do governo no sentido de que essas instituições ampliassem seus financiamentos encontrava correspondência em um grande crescimento da sua captação de recursos, dada a maior preferência do público em manter, no momento de crise, seus saldos de recursos junto aos bancos oficiais. No caso do BNDES, suas operações de crédito já vinham aumentando de forma acelerada antes da crise em função do boom de investimentos em grandes projetos que após uma ausência de mais de três décadas voltou a se apresentar na economia brasileira. Nesse caso, a orientação do governo foi não interromper o financiamento das inversões que de outra forma não seriam realizadas, dada a retração do crédito externo e doméstico e o refluxo que se observava no mercado brasileiro de capitais. Além disso, como já foi visto, o BNDES financiou oportunidades abertas pela crise para aquisições e fusões sob o comando de empresas nacionais, no país e no exterior.

Em suma, propriamente relacionados à defesa do nível de atividade durante a crise e indutores da recuperação após a recessão do ultimo trimestre de 2008 e primeiro trimestre de 2009 , podem ser relacionados (i) os instrumentos monetário o qual, todavia, veio com relativo atraso, (ii) o instrumento fiscal que, no entanto, pode ser considerado tímido se comparado aos esforços empreendidos em outros países, (iii) o instrumento da liquidez, que mais propriamente defendeu o sistema bancário contra o risco de uma crise e (iv) o crédito dos bancos públicos, este sim, o mais ativo promotor da defesa da economia contra a crise e da restauração das condições de volta do crescimento.

Ao lado desses fatores, foi decisiva a manutenção pelo governo das políticas que já estavam em curso, o que teve por consequência a preservação, durante a crise, de certo de nível de gasto e de crédito na economia. Assim, o governo não abriu mão dos vultosos investimentos programados pela Petrobras e dos demais programas do PAC e procurou ampliar esses investimentos. Criou também dois outros programas relevantes. O primeiro, na área de habitação ("Minha casa, minha vida"), terá maior impacto a partir de 2010; o segundo, transitório (com validade até 31/12/2009, depois prorrogado para o fim de 2010), foi adotado em meados de 2009 na área do investimento. O "Programa de Sustentação do Investimento" (PSI) pode ser concebido como um capítulo da exitosa política de crédito adotada durante a crise e teve grande efeito sobre o investimento corrente, notadamente no investimento mais "leve" (voltado à aquisição de máquinas e equipamentos). Consistiu na redução para $4,5 \%$ ao ano da taxa de juros dos financiamentos do BNDES para a compra de bens de capital, praticamente tornando nula a taxa real de juros dos financiamentos de parcela considerável do investimento no país.

Não houve retrocesso em outras decisões do governo como ampliar e reajustar as transferências para famílias pobres (o programa "Bolsa Família") e na concessão de aumento do salário mínimo. O governo também não restringiu o direcionamento do crédito, como por exemplo, no sistema que vin- 
cula a captação da caderneta de poupança que teve significativo aumento no ano da crise com o financiamento de moradias. Com isso, foi possível amortecer a queda no setor de construção habitacional. Não houve recuos ainda em programas de elevação dos salários de servidores públicos, mas nesse caso um adiamento ou reprogramação não teria ônus para o crescimento econômico. Com essas medidas, às quais se somariam outras como a ampliação do seguro desemprego, o governo preservou o seu já elevado nível de gasto público sobre o PIB, aumentou o investimento público e ampliou o impacto do gasto por ele induzido na economia.

Isso teve consequência relevante porque evitou que a crise se propagasse para toda a economia brasileira. A sustentação do gasto público "blindou" o setor serviços da economia, responsável por $60 \%$ do PIB e grande empregador. Este setor, salvo em segmentos de maior relação como a dinâmica agroindustrial, a exemplo de transportes, praticamente não foi afetado pela crise. Isso significa dizer que os efeitos desta no Brasil, embora graves, ficaram restritos aos setores da indústria e da agropecuária. Nesses casos era inevitável um grande impacto inicial da crise internacional, dada a sua natureza tratou-se de uma ampla e gravíssima crise de confiança - e as mudanças por ela repentinamente provocadas nas decisões de longo prazo, na disponibilidade do crédito e no comércio exterior. Isso afetaria fortemente a agropecuária (pelo encolhimento do crédito e do comércio mundial) e, sobretudo, a indústria (pelos mesmos fatores, acrescidos da retração do investimento em decorrência do colapso das decisões de longo prazo). Por essas razões, o primeiro desses setores declinaria $5,2 \%$ no ano da crise, a indústria, $5,5 \%$, enquanto o setor de serviços mantinha crescimento de $2,6 \%$.

Por outro lado, o gasto público, na medida em que preservou o emprego no setor de serviços, protegeu a atividade em segmentos produtores de alimentos e de bens industriais básicos para a população. Isso não impediu, no entanto, uma onda de demissões com dispensas líquidas de trabalhadores formais acumuladas entre outubro de 2008 a março de 2009 de 692 mil pessoas. Mas, apesar disso, deve ser notado que as demissões ocorreram na indústria (493 mil) e agropecuária (227 mil), mas não no comércio (que no mesmo período contratou 47 mil pessoas) e em serviços (67 mil). Deve ser sublinhado ainda que após esse período todos os setores ampliaram as contratações.

Por não prosperar o desemprego, não aumentou a inadimplência no crédito familiar. Isso, aliado à disposição dos bancos oficiais de deterem fatia maior no crédito pessoal e ao consumidor, o que suscitou uma reação competitiva da parte do segmento privado, fez com que já no segundo trimestre de 2009 voltasse a crescer o crédito para as pessoas físicas. No segundo semestre ocorreria um início de retomada do crédito para as empresas.

Em suma, a manutenção e o aumento do nível do investimento e do gasto público e a ampliação do crédito em plena crise, foram os determinantes do êxito brasileiro em responder à crise internacional e superá-la com rapidez, minimizando a retração do PIB em 2009. A ampliação do crédito pode ser considerada fator ativo mais relevante para a retomada do crescimento da economia a partir do segundo trimestre do ano passado. Se o Brasil tivesse se aproximado mais de outros países em termos de arrojo na execução de políticas fiscais e de juros, como no caso da China e dos países desenvolvidos, talvez sua economia nem tivesse entrado em recessão e teria acumulado crescimento no ano crítico de 2009.

\section{Câmbio, investimento, poupança e conta corrente no Brasil}

\section{MARCO FLÁVIO DA CUNHA RESENDE ${ }^{17}$}

Após apresentar um desempenho pífio em 2009, consequência da crise financeira mundial, a economia brasileira voltou a crescer em ritmo acelerado em 2010. Todavia, se a deterioração do saldo em transações correntes que está em curso não for estancada, corre-se o risco de se ter mais à frente uma inflexão no ciclo de crescimento brasileiro. Esta possibilidade é reforçada pela retomada da crise na zona do Euro que produz para os próximos anos um quadro pouco auspicioso para o sistema financeiro inter-

\footnotetext{
${ }^{17}$ Professor de Economia do CEDEPLAR-UFMG. E-mail: resende@cedeplar.ufmg.br.
} 
nacional. $\mathrm{O}$ agravamento da crise afeta de modo negativo, quer o potencial de financiamento dos déficits em transações correntes, quer o desempenho exportador do Brasil.

Portanto, faz-se necessário reverter o quadro atual de deterioração do saldo das contas externas visando à sustentabilidade do ciclo de crescimento da economia brasileira que se inicia. É comum o argumento de que o desequilíbrio fiscal do setor público é o responsável pelo crescimento com poupança externa na medida em que provoca a insuficiência de poupança doméstica em relação a uma dada taxa de investimento. Neste contexto, argumenta-se, por exemplo, que a economia chinesa cresce muito porque sua taxa de poupança é elevada, enquanto no Brasil a taxa de poupança é pequena e, por isso, seu crescimento requer a absorção de poupança externa, que se manifesta por meio de déficits em transações correntes. Embora esteja disseminada a ideia de que a poupança é um pré-requisito para o investimento, este argumento não é consensual na literatura.

Keynes demonstrou que a poupança decorre da renda e esta depende do investimento. Ou seja, o investimento gera a renda, que, por sua vez, cresce como um múltiplo do investimento (multiplicador dos gastos), e, após este processo, parcela da renda é poupada. A poupança é igual ao investimento ex post, mas é este que causa aquela; e não o contrário. $\mathrm{O}$ investimento não depende da poupança, mas, sim, uma vez tomadas as decisões de investir tendo como base o animal spirits dos empresários, do crédito de curto prazo demandado pelas firmas no intervalo de tempo entre a decisão de investir e sua implementação, visando financiar a produção de bens de capital. Essa demanda de crédito foi denominada por Keynes de finance motive, que surge de arranjos financeiros de débito e crédito que não necessariamente apresentam como lastro uma poupança ou coisa que o valha. Assim sendo, o papel da poupança é consolidar (mas não financiar) o investimento e, por conseguinte, a acumulação de capital. A crise do subprime é um exemplo deste modus operandis da economia capitalista, na qual a esfera financeira se descolou, e muito, da esfera real da economia. $\mathrm{O}$ adiantamento de recursos, criado a partir de arranjos financeiros, viabiliza o investimento, a geração de renda e, a partir de então, a poupança que será utilizada para superar a vulnerabilidade financeira criada para credores e devedores quando aqueles concederam o finance para o investimento.

Se é o investimento que causa a poupança, conclui-se que a China cresce muito e poupa muito porque investe muito, enquanto o Brasil poupa pouco porque investe pouco. No Brasil os investimentos privado e público são baixos. O governo investe pouco porque grande parte de sua arrecadação destina-se ao consumo e ao pagamento de elevadas taxas de juros incidentes sobre a dívida pública. A questão que se apresenta é a seguinte: por que no Brasil há baixas taxas de investimento e de poupança doméstica, além de crescente absorção de poupança externa (déficit em transações correntes, CC), enquanto na China há elevadas taxas de investimento e de poupança doméstica e externa (superávit em CC)? A resposta para esta questão nos remete a outra controvérsia presente na literatura econômica.

Não há consenso sobre as causas do déficit em CC. Duas causas são frequentemente apontadas. A apreciação da taxa de câmbio real implica alteração de preços relativos (bens comercializáveis vis-à-vis bens não comercializáveis), afetando os saldos comerciais e em CC. Há, também, o argumento de que o déficit público implica insuficiência de poupança nacional em relação ao investimento, resultando em déficit em CC. Ocorre, então, absorção de poupança externa (déficit em CC) para compensar a insuficiência de poupança nacional - esta é a tese dos déficits gêmeos.

Ou seja, o investimento corresponde ao aumento do estoque de capital físico da economia e, em equilíbrio macroeconômico (ex post), é contabilmente igual à soma das poupanças nacional e externa. Assim, a poupança nacional é a renda nacional não consumida e tem como contrapartida a produção de capital que irá satisfazer a demanda de investimento. Se o déficit público implica aumento do consumo para um dado nível de renda, argumenta-se que haverá insuficiência da poupança nacional para um dado nível de investimento. O resultado é a absorção de poupança externa (déficit em CC). Todavia, os mecanismos através dos quais este processo se manifestaria não são claros.

Tavares et al. (1982, p. 35, “A questão da poupança: desfazendo confusões”. In: Tavares, M.C. e David, M.D. (org), A Economia Política da Crise, Rio de Janeiro, Vozes) argumentam que tal processo não é concretamente possível visto que em certo momento do tempo o estoque de capital da economia está dado. Deste modo, o aumento da absorção doméstica não pode transformar bens de capital (BK) destinados à produção de BK em BK destinados à produção de bens de consumo, e vice-versa. Neste caso, o déficit público não reduz a disponibilidade interna de máquinas e equipamentos requeridos para o investimento e, então, seriam falaciosas as relações entre déficit público, insuficiência de poupança nacional e déficit externo.

Porém, este argumento só é válido para economias fechadas. Se alterações na absorção doméstica vierem acompanhadas de mudanças dos preços relativos haverá mudanças na oferta de bens de investi- 
mento, alterando a poupança nacional, em economias abertas. Assim sendo, através da depreciação (apreciação) da taxa de câmbio real a poupança nacional pode ser ampliada (reduzida).

O aumento da absorção doméstica acima de uma dada taxa de crescimento do produto potencial, quando acompanhado de apreciação da taxa de câmbio real, reduz as exportações líquidas, inibindo a oferta de bens de investimento (BK) que ocorre por meio de importações, em um contexto de equilíbrio externo. Para que tal oferta não se reduza, torna-se necessário manter o nível das importações de BK, apesar da queda das exportações líquidas, deteriorando-se o saldo em CC.

Resende (2009, "Déficits Gêmeos e Poupança Nacional”, Revista de Economia Política, v. 29, n¹, 113) demonstrou que não há uma relação de causalidade sistemática entre déficit público e apreciação da taxa de câmbio real, mesmo quando se considera a ausência de "equivalência ricardiana" e de crowding out. Isto é, não é sempre que o déficit público produz apreciação da taxa de câmbio real e déficit externo (nem sempre prevalece a tese dos déficits gêmeos).

Assim sendo, é um falso dilema a controvérsia sobre as causas do déficit em CC, quais sejam, a apreciação da taxa de câmbio real e o excesso de absorção doméstica — sendo tal excesso muitas vezes causado pelo déficit público. Este último pode ensejar o déficit em CC quando provoca a apreciação da taxa de câmbio real. A apreciação cambial, por sua vez, implicaria insuficiência de poupança nacional para uma dada taxa de investimento e também deterioração do saldo em CC. Mas esta última seria o resultado da insuficiência de poupança nacional ou da apreciação cambial?

Quando o déficit público implica apreciação da taxa de câmbio real, parcela da demanda de investimentos é deslocada para o exterior, afetando a taxa de poupança nacional. O aumento do preço relativo dos bens não comerciáveis enseja aumento da demanda doméstica por bens comerciáveis e redução da produção doméstica destes. Assim, a apreciação do câmbio real reduz a disponibilidade doméstica de BK, entendida como a soma da produção doméstica de BK destinada ao mercado interno e das importações destes bens até o ponto onde o saldo em transações correntes se equilibra. Após a apreciação da taxa de câmbio real torna-se necessário manter ou até aumentar o volume de importação (de BK) de modo a viabilizar dado volume de investimento, deteriorando-se o saldo em CC. Então, a parcela do investimento total que corresponde à demanda de BK satisfeita através da compra destes bens no mercado interno e da importação de BK até o ponto onde o saldo em transações correntes se equilibra, se reduz após a apreciação da taxa de câmbio real, ensejando na mesma medida um menor volume de poupança nacional.

Quando a apreciação cambial ocorre, verificam-se, simultaneamente, deterioração do saldo em CC, queda da poupança nacional e reorientação para o exterior do estímulo à formação de poupança proporcionado pelo investimento. Estes três processos são faces da mesma moeda. Quando a taxa de câmbio real se aprecia as exportações líquidas caem. Assim, a parcela do investimento que corresponde às importações de BK que antes da apreciação cambial estimulava a formação de poupança nacional através das exportações, passa a estimular a formação de poupança no exterior, após a apreciação cambial, se não vejamos.

O investimento gera renda e, via multiplicador dos gastos, gera a poupança nacional na economia fechada. Na economia aberta, este papel do investimento também é exercido pelas exportações: a exportação gera renda e, via multiplicador, surge a poupança. A receita das exportações é usada para a importação de BK, ou seja, tudo se passa como se as exportações fossem a própria produção doméstica de BK, visto que a receita das exportações é trocada por importação de BK. Quando a taxa de câmbio real se aprecia, surgem de modo simultâneo deterioração do saldo em CC e queda da poupança nacional, estando ambos os processos associados à contração das exportações líquidas. Uma vez que estas se reduziram após a apreciação cambial, não haverá mais a troca de bens exportados por importações de BK, pelo menos parcialmente. Após a apreciação cambial parcela das importações de BK e, portanto, parcela do investimento, terá sua correspondência na absorção de poupança externa (déficit em CC). Do ponto de vista do resto do mundo (ou dos parceiros comerciais), suas exportações líquidas terão aumentado após a apreciação da taxa de câmbio real no país doméstico. Isto quer dizer que o investimento precede a poupança, mas, após a apreciação cambial parcela do investimento (importações de BK) do país doméstico passou a estimular a formação de poupança no resto do mundo e deixou de estimular a formação da poupança no país doméstico.

Este é o caso do Brasil. Não se trata de insuficiência de poupança em relação a uma dada taxa do investimento doméstico. Partindo de um dado nível do investimento doméstico, o câmbio apreciado enseja déficit em CC estimulando a formação de poupança no resto do mundo a partir do investimento doméstico, enquanto o estímulo sobre a renda e sobre a poupança brasileira fica reduzido. Eis por que, no Brasil, a reduzida taxa de investimento convive com uma taxa de poupança doméstica ainda menor e com absorção de poupança externa. Na China, o câmbio depreciado produz um resultado diferente. 